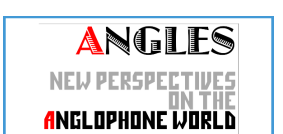

ANELOPHONE WORLD

\section{Angles}

New Perspectives on the Anglophone World

$11 \mid 2020$

Are You Game?

\title{
Blue Balls of Fire and the Ethics of Spectatorship: Verlaine, Yeats, Beckett
}

\section{Alexandra Poulain}

\section{(2) OpenEdition}

1 Journals

\section{Electronic version}

URL: https://journals.openedition.org/angles/2432

DOI: $10.4000 /$ angles.2432

ISSN: 2274-2042

\section{Publisher}

Société des Anglicistes de l'Enseignement Supérieur

\section{Electronic reference}

Alexandra Poulain, "Blue Balls of Fire and the Ethics of Spectatorship: Verlaine, Yeats, Beckett", Angles [Online], 11 | 2020, Online since 01 November 2020, connection on 06 June 2022. URL: http:// journals.openedition.org/angles/2432 ; DOI: https://doi.org/10.4000/angles.2432

This text was automatically generated on 6 June 2022

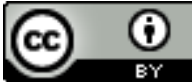

Angles est mise à disposition selon les termes de la Licence Creative Commons Attribution 4.0 International. 


\title{
Blue Balls of Fire and the Ethics of Spectatorship: Verlaine, Yeats, Beckett
}

\author{
Alexandra Poulain
}

1 This paper looks at three short dramatic scenes by Paul Verlaine, W. B. Yeats and Samuel Beckett which all pick up that most conventional of theatrical themes, thwarted love, only in a disturbing way, by shifting the focus from the torments of the soul to the painful embodied experience of sexual frustration, and by having it performed not by youthful "star-crossed lovers", but by ambiguously incarnated revenants, or by decrepit, nearly dead old people. I want to suggest first that a certain filiation, conscious or not, runs from one of Verlaine's most famous poems, "Colloque sentimental", through the dance of the ghosts in Yeats's "play for dancers" The

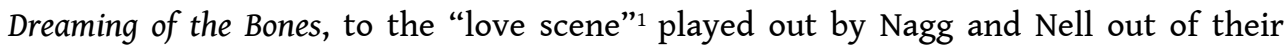
respective dustbins in Beckett's Endgame. More importantly, I argue that the three pieces ask uncomfortable questions about the ethics of spectatorship, and invite us to think critically about the conceptualising of theatre as "face-to-face encounter with the Other", a notion inspired by Levinas which has gained currency since the "ethical turn" hit theatre studies in the mid-2000s. ${ }^{2}$ This paradigm, I suggest, is applied inaccurately to the theatrical encounter, especially in such contemporary productions as Milo Rau's 2019 show Orestes in Mosul, which really rests on a problematic ethics of empathy. The three scenes by Verlaine, Yeats and Beckett, on the other hand, offer an alternative model of unempathetic spectatorship which, paradoxically, may go further towards allowing the presence of radical Others on the stage.

\section{Thwarted Love, Grotesque Bodies}

2 "Colloque sentimental" is the last poem in Verlaine's early collection Fêtes galantes, published in 1869, just a few years before his encounter with Rimbaud. It consists of a dialogue in direct speech between two "spectres" reminiscing about past love, framed 
by a deceptively simple narrative. The title, which is left in French in most English translations, ${ }^{3}$ is largely ironic and foregrounds the asymmetry between the two ghosts, only one of whom is actually being "sentimental", while the other remains cold and indifferent, and refuses to join in a nostalgic evocation of past romance. The two ghosts are not gendered; in fact, they appear at first only as nondescript "shapes" ("formes") in the dark of night (1. 2), and in the reprise 1.6 as "spectres" ("ghosts" in Symons, "shadows" in Dowson), although it remains unclear whether this term is metaphorical (since the dialogue is completely banal and could be spoken by any old couple) or literal. The dialogue is contained within four of the eight rhyming couplets of the poem, each of which contains the first ghost's eager openings and the second ghost's cool rebukes. The asymmetry is conveyed dramatically by the uneven distribution of speech in the middle stanzas (1. 9-12), where the first ghost's cues take up almost the whole couplets, and the second ghost's responses are correspondingly laconic. It is also inscribed in the disparity of grammatical modes of address, the first ghost addressing the second with the intimate "tu" (the second person singular), the second answering with the more formal, distance-inducing "vous" (the second person plural) - an effect which Dowson tried to recreate unconvincingly by resorting to the archaic "thou" in English. While the first ghost at first churns out abstruse sentimental clichés, to the second ghost's evident disgust - "notre extase ancienne" (1. 7), “Ton cœur bat-il toujours à mon seul nom?" (Symons, 1. 9), "Toujours vois-tu mon âme en rêve?" (1. 10) - , he or she eventually conjures up the memory of past kisses, expressed in a straightforward, intensely erotic phrase: "quand nous joignions nos bouches" (l. 12). The second ghost's refusal of nostalgic exaltation, his or her radical grounding in the gloomy present rather than the hopeful past, makes the reiteration of past kisses impossible. While the two spectres glide through the night together, the dialogue both materialises their intimacy and drives a wedge between them. They might be in a kind of proto-beckettian infernal afterlife, rehearsing forever their past love, substituting empty words for carnal embrace.

3 Yeats first encountered Verlaine's poetry in 1890 when he founded the Rhymers' Club with Ernest Rhys in London. Among the two dozen (male) poets who met regularly in the Cheshire Cheese pub under the Club's auspices were Arthur Symons and Ernest Dowson, both of whom were acquainted with Verlaine's works. Symons in particular soon became Yeats's intimate friend, and read him Verlaine and Mallarmé's poems, which he was translating, helping Yeats whose grasp of French was always abysmal despite his lifelong effort to learn the language. In 1894, for his first trip to the Continent, Yeats travelled to Paris with Symons, and visited Verlaine "at the top of a tenement house on the Rue St. Jacques" (Yeats 1999: 261) - luckily Verlaine was able to chat to him in English. Yeats was impressed by the dual nature of Verlaine, whom he saw as divided between spiritual elevation and beastliness, and recorded the occasion in a highly colourful passage of his Autobiographies. The poem "Colloque Sentimental" did not feature among Symons' translations of Verlaine published in the second edition of his collection Silhouettes in $1896,{ }^{5}$ but it appears in the enlarged edition of his influential essay The Symbolist Movement in Literature published in 1919, the same year Yeats published the Noh-inspired play The Dreaming of the Bones (which was staged much later at the Abbey Theatre, in 1931). ${ }^{6}$ Yeats's play is set in the immediate aftermath of the Easter Rising in 1916: a young rebel has fled to the West coast of Ireland, where he encounters a Stranger and a Young Girl at night. As they walk together up a mountain-top, he gradually discovers them to be the ghosts of Diarmuid 
and Devorgilla, the King of Leinster and his adulterous lover who, according to legend, "brought the Norman in" (Yeats 2001: 314) to help them fight off Devorgilla's jealous husband Tiernan O'Rourke in 1166, thus starting the colonization of Ireland. As a penance for betraying their country for the sake of love, they have been condemned to stay together in the afterlife without ever being able to kiss or embrace each other. Whenever they come too close, the memory of their guilt drives them apart again. The cruelty of this punishment is conveyed by the Young Girl in one simple, coldly regular iambic pentameter: "Though eyes can meet, their lips can never meet." (313) The barrier of guilt which keeps them apart is materialised by the hemistich, separating "can" from "can never". As in Verlaine's poem, the ghosts' bodies are invoked by way of synecdoche in terms of "eyes" and "lips", but here the obstacle to erotic fulfilment is not the asymmetry of desire but an external constraint, the curse that keeps them in a loop of perpetual desire and frustration, and that they perform in a dance which the Young Man describes as he tries to make sense of it:

why do you dance?

Why do you gaze, and with so passionate eyes,

One on the other; and then turn away,

Covering your eyes, and weave it a dance? (315)

4 The whirling rhythm of the lines and the repetitions (the anaphoric "Why do you", the sequence gaze-eyes-eyes, and the epistrophe with "dance" at the end of lines 1 and 4) create a flowing movement, the verbal counterpart of the dance which the words describe, ${ }^{7}$ interrupted by the semi-colon at the hemistich of the third line, which again materialises the invisible obstacle that keeps them separated and forces them to perform the dance in a loop. The curse might be lifted, the Young Girl explains, if "somebody of their race" agreed to forgive them, but on two occasions the Young Man, who has just been fighting for the freedom of Ireland, decrees that "never, never / Shall Diarmuid and Devorgilla be forgiven" (314-5), thus in effect keeping the dance going, instead of freeing the ghosts from their penance and purging the revolutionary present from the haunting of past betrayals.

The ghosts' dance, with its contradictory centripetal and centrifugal movement, anticipates the grotesque "love scene" played out by Nagg and Nell out of their dustbins in Beckett's Endgame. In what is arguably the play's most outrageous passage, the old people push against the lids of the dustbins in which their son Hamm keeps them "bottled" (Beckett 2009: 17):

Nagg: Kiss me.

Nell: We can't.

Nagg: Try.

Their heads strain towards each other, fail to meet, fall apart again.

Nell: Why this farce, day after day? (12)

In Beckett's sardonic rewriting of Yeats, the graceful dance of the ghosts, who have kept their youthful appearance (Yeats 2001: 312), is translated into the grotesque clowning of two elderly half-corpses who are literally falling apart: they are legless, hard of hearing, almost blind, and Nagg mentions he has just lost his last tooth, making the perspective of the kiss particularly unlike the conventional representations of erotic encounters which saturate literature and art. Here the graceful dance of the Yeatsian ghosts is reinterpreted as a minimalist choreography in which the two dustbin-bound bodies, defying stasis and death, merely lean towards each other and back again. The endless penance of the traitorous ghosts in The Dreaming of the Bones in 
the afterlife returns as a meaningless "farce" which must still be played out "day after day" in this life, unmotivated yet inevitable - both the grim "farce" of old age and decay which must be played out until death, and the weird "farce" that this unclassifiable play is, played "day after day" to bemused audiences who may well be wondering "why". Beckett was also very familiar with Verlaine's poem, from which he borrows the title of another play, Oh les beaux jours! (Happy Days), a deliberate misquotation of Verlaine's "Ah les beaux jours..." In this scene, he adapts Verlaine's sardonic resort to nostalgia (Nagg and Nell reminisce "elegiacally" about past luxuries, such as having sawdust instead of sand in their dustbins), as well as his use of asymmetry between the two lovers. Nagg is much more eager than Nell, who is a step closer to death than he is (she will be pronounced dead soon after this scene). He is the one who initiates the ritual of the kiss despite Nell's reluctance ("Kiss me - We can't Try"). When this fails, as it always does, he launches into a long-winded story calculated to cheer up Nell and restore a symbolic, rather than physical, form of intimacy between them, although she has no interest in hearing it. In a nutshell: an Englishman orders a pair of trousers from a tailor, who repeatedly fails to deliver on time because he has botched the crotch area. This makes for a series of obscene puns ("a snug crutch is always a teaser", "I've made a balls of the fly", "a smart fly is always a stiff proposition", etc.), and for a punchline which recycles the epigraph to Beckett's earlier essay "La Peinture des van Velde ou le Monde et le Pantalon", written in 1945:

[Customer's voice.] 'God damn you to hell, Sir, no, it's indecent, there are limits! In six days, do you hear me, six days, God made the world! Yes Sir, no less, the WORLD! And you are not bloody well capable of making me a pair of trousers in three months!' [Tailor's voice, scandalized.] 'But my dear Sir, my dear Sir, look - [disdainful gesture] - at the world - [pause] - and look - [loving gesture, proudly] - at my TROUSERS!' (Beckett 2009: 16)

7 The joke encapsulates Beckett's take on the inevitability of creative failure. After the debacle of Genesis ("look at the world!"), all subsequent acts of creation can only hope to emulate God's initial failure. The tailor never completes his trousers, and Nagg, in his desperate attempt to cheer up Nell, only botches up his rendition of the story. Disgusted with his own narrative incompetence, Nagg accelerates towards the end of the story: "Well, to make it short, the bluebells are blowing and he ballockses the buttonholes." (16) When I taught Endgame in a seminar last year, one of my students suggested that this line contains the hidden signifier "blue balls". 9 (For those who, like me at the time, may not be familiar with this phrase, "blue balls" refers to "pain of the testes and scrotum occurring after prolonged sexual arousal without orgasm." ${ }^{10}$ ) "Blue balls", of course, are what the "story of the tailor" both attempts to defuse (by diverting Nagg's attention from the frustration of the failed kiss) and recreates by endlessly delaying the (failed) climax of the punchline. Whether or not Beckett actually had the phrase in mind (he probably did), it is in tune with the play's focus on dysfunctional bodies. "Blue" is both metaphorical and literal: it connotes melancholia but locates its source in a grotesque, graphically aberrant body.

\section{The Reluctant Spectator}

The three pieces thus revisit the old theatrical theme of thwarted love by staging bodies not conventionally associated with representations of love (ambiguous spectres or very old people) and by emphatically supplementing feelings (heartbreak) with 
grotesque physical pain (blue balls). The three couples are either dead or dying, but they perform both a metaphysical and an aesthetic transgression by appropriating the life-force of desire on the stage of the living. Something else also unites the three pieces: the presence of a reluctant spectator. While Verlaine's poem and Yeats's play are set at night, when the presence of the ghosts is hardly discernible, the scene in Endgame, lit by the ubiquitous Beckettian "grey light", is witnessed by Hamm, who is blind. The onstage spectators in the three scenes are thus blissfully saved from having to see anything, but they are also desperate not to hear. Much of the dramatic intensity of "Colloque sentimental" comes from the poem's paradoxical treatment of the narrator - a presence, a witness to the scene who tries very hard to deny that he or she was ever there, and to disappear from the surface of the text. The only syntactic inscription of the narrator in the poem concerns, symptomatically, the act of (hardly) hearing: "Et l'on entend à peine leur paroles" (1. 4). The narrator is implicitly present but disappears behind an indefinite grammatical subject ("on"), translated by the passive voice in Symons, and the rather awkward "a man" in Dowson. But even this minimalistic form of inscription is later denied in the final line, which revises line 4 and performs the erasure of the narrator's presence: "Et la nuit seule entendit leurs paroles." Of course, the poem itself, by recording the dialogue of the spectres in direct speech, invalidates this claim of absence (someone must have heard since we now have the poem), and indeed the narrator's reluctant presence is subtly suggested throughout the text. The title with its sarcastic tone creates a distinctive narrative voice which is far from impersonal. This voice is then materialised in the singsong dactylic rhythm of the poem (an unusual rhythm in French poetry) which suggests a kind of flippancy, as if the narrator were mocking the ghosts' predicament. Yet this apparent flippancy is challenged by the gloomy tone of the opening line. The description of the setting is apparently impersonal and objective, yet can be read as an extended hypallage (a figure of speech in which an adjective describes something or someone else than the noun to which is it attached grammatically). All three adjectives attached to the noun "parc" ("vieux", "solitaire", "glacé") apply rather awkwardly to a park, and more convincingly to a human presence. It might be argued that they apply to the "spectres" who appear as an emanation of the gloom, although they are walking and talking together and thus don't quite come across as "solitary". The adjectives might just as well apply to the narrator, who in typically Verlainian fashion is trying to conceal a deep melancholia behind a surface of sprightly carelessness - and now we have not only a recognisable voice but a complex persona fleshed out of the text's silences, a witness who is trying to disappear from the scene, yet reluctantly bears witness to it.

In Yeats and Beckett, the presence of the reluctant spectator is more straightforward: this is theatre, and both the dance of the ghosts in The Dreaming of the Bones and the love scene in Endgame are witnessed by onstage embodied spectators. The dance of the ghosts is both a performance of the ghosts' penance and an appeal to the Young Man's feelings: he is "of their race" and could lift the curse by granting them forgiveness. The Young Man watches the dance and describes it, yet denies them forgiveness. Ironically, in refusing to listen to their pain and to intervene, he ensures that the performance will go on forever. In Endgame, the blind, wheelchair-bound Hamm has nowhere to go, and is forced to listen to his parents' love scene. The violent power relations are both very clearly delineated in the play, and always reversible: Hamm keeps his decrepit parents "bottled" in their dustbins, yet when they push up their lids and impose their presence on the stage he becomes, literally, their captive audience, trapped in a kind of 
Freudian nightmare where he is forced to witness the "primal scene" of his parents' lovemaking. No wonder that he is a reluctant spectator; not only is he blind, but he also wishes he were deaf, and tries to silence the old couple:

Hamm (wearily): Quiet, quiet, you're keeping me awake. (Pause) Talk softer. (Pause) If

I could sleep I might make love. (Beckett 2009: 14)

10 The implication of rivalry is clear: if his parents only shut up, he might live out his own erotic fantasy (if only in a dream) instead of having to witness their grotesque amorous ritual. Yet by keeping them confined in separate dustbins, he provides the scenographic arrangement that keeps them apart and forces them to perform "this farce, day after day". In all three cases, then, the reluctant spectator is somehow responsible for the lovers' presence on the stage which he or she shares with them. In "Colloque sentimental", the figure of the "reluctant spectator" is the elusive narrator, who is perhaps even ghostlier than the ghosts themselves: the poem's effectiveness thus relies on a sophisticated handling of voices, a construction which highlights its highly self-conscious literariness, despite its apparent simplicity. In The Dreaming of the Bones and Endgame, on the other hand, the embodied presence of the "reluctant spectator" on the stage opens up a space for a metatheatrical reflexion about the ethics of spectatorship.

11 I now want to suggest that the paradigm of the reluctant spectator, as we have encountered it in the fictional worlds of Verlaine, Yeats and Beckett, offers a productive counter-model to a recent but ubiquitous discourse about theatre and ethics in the real world.

\section{3. "Face to Face" (Really?)}

Since the ethical turn in literary criticism hit the field of theatre and performance studies in the mid-2000s, many critics (eg. Phelan 2004; Read 2005; Grehan 2009; Jeffers 2012) have invoked, more or less critically, Levinas's concept of the face-to-face encounter with the Other as particularly suited to account for the ethical obligation inherent in the theatrical experience. To summarise a complex notion, Levinas contends that our human existence is grounded in the encounter of the "face" of the Other, for whom we are obligated to recognise an infinite responsibility. While the "face" remains an abstract concept for Levinas, theatre critics often transpose his ethical thinking to the literal "face-to-face encounter" which allegedly occurs between actor and audience in the theatre. To quote Mireia Aragay:

Theatre and performance may even appear, from a Levinasian perspective, as privileged cultural practices as regards the exploration of ethical issues since they seem to be based, almost literally, on co-presence, on the face-to-face encounter between embodied, vulnerable spectators and Others wherein the former are summoned to respond, to become actively engaged in an exemplary exercise of ethical 'response-ability'. (Aragay 4-5) ${ }^{11}$

One senses the hesitancy in the above quotation, and indeed Aragay, after others, cautions against such a literal understanding of Levinasian ethics, and questions its relevance to the theatrical experience, pointing out, among other things, Levinas's "profound suspicion of aesthetic representation" (5). In his book Theatre, Intimacy and Engagement: The Last Human Venue (2009), Alan Read questions his own earlier embrace of the paradigm of the "face-to-face encounter" between spectators and actors and provocatively claims that "the one thing that is obvious from any witness of 
performance, even to the most passing eye, is the lack of anything that could be described as 'face engagement."' (Read 2009: 36) He continues:

There are face-to-face encounters in the theatre but there should be no presumptions that these encounters occur across the footlights, between performer and audience in a school-gymnasium, nor between the Boalian Joker and witnesses in a Romanian orphanage. They are much more likely to occur with another set of actors whose ciphers should not obscure the fact that their engagement with us operates on an adjacent yet concrete economy: meetings with the usherette, the barman and the ticket seller, the janitor, the pupil and the parent, the management, the resident and the orphan, are far more facially specific encounters than theatre agents, called actors, can maintain. (37)

While the transposition of Levinas's concept of the "face-to-face encounter" does not really suffer literal transposition to the concrete experience of a performance, it is also questionable whether the kind of encounter that does occur in the theatre necessarily entails a confrontation with radical otherness. Commenting on Hans-Thies Lehman's notion of "responsibility" in his influential Post-Dramatic Theatre (1999), a book which only references Levinas in passing but seems to riff on the Levinasian notion of ethical responsibility, Nicholas Ridout remarks:

Spectators are called upon to recognise that there is a relationship between what is shown in the theatre and their own experience of the world. In responding to this call, spectators take responsibility for making what is shown part of their personal experience. The spectators are invited to do something about it. (Ridout 59)

As Ridout points out, when we attend performances that demand from us a form of responsibility, "perhaps we are responding not to the 'other' but to 'the same', to a reflection of our own 'self."' (66) I would add that behind the hasty transposition of the Levinasian concept of the face-to-face encounter with the Other to audience-actor encounters in the context of performance, what often seems to be at stake is empathy, that most un-Levinasian notion which has been critiqued in much postmodern thinking about ethics. ${ }^{12}$ Rae D. Greiner defines empathy as "a way for the ego to gaze upon itself and transport itself into the minds and bodies of others" (Greiner 418). The violent narcissistic potential of empathy implicit in this definition is expressed explicitly in Jonathan Boyarin's Storm from Paradise: The Politics of Jewish Memory (1992). Noting that the otherness of Jews has been occluded in the West since WWII, he suggests that one reason is "the hegemony of empathy as an ethic of the obliteration of otherness" and notes "the repressive effects of empathy on those who remain beyond the Pale" (Boyarin 86) - those whose otherness, in other words, cannot be assimilated into sameness.

It is precisely those radical others who are staged in the three pieces I have been considering. In Verlaine and Yeats, the radical others are revenants, literally from "beyond the pale" of death, who refuse to stay dead and return to haunt the world of the living, conjuring up past intimacy and attempting (in vain) to recreate it in the present, as shared reminiscence in Verlaine, and embodied dance in Yeats. Their usurpation of the life-force - of the sex drive - creates a metaphysical disturbance in the world of the living, and they can never be perceived as "the same". In Beckett, the old couple are nearing death, and by the ageist, ableist standards of Western modernity, they should know better than to take to the stage like young star-crossed lovers. The fact that Hamm keeps them in dustbins graphically expresses the violence of the modern utilitarian ethos according to which bodies that can no longer work productively (or, indeed, reproductively) are considered useless, human detritus to be 
stowed away and disposed of. The dustbins anticipate coffins - replace them in fact, since in the dystopian world of the play where all vital resources are fast disappearing, "there are no more coffins" (Beckett 2009: 46). It may be useful here to invoke Julia Kristeva's concept of the abject to account for Hamm's revulsion, his incapacity to empathise with Nagg and Nell. The abject, says Kristeva in Powers of Horror (1982), is a fallen object, which threatens my identity unless I expel it from myself, reconstituting my own integrity in the process. Corpses (or cadavers, from the Latin cadere, to fall) are the ultimate expression of abjection, bodies like mine which have fallen into death, and which I must push away to stay alive. Kristeva points out the power of disturbance of the abject:

It is thus not lack of cleanliness or health that causes abjection but what disturbs identity, system, order. What does not respect borders, positions, rules. The inbetween, the ambiguous, the composite. The traitor, the liar, the criminal with a good conscience, the shameless rapist, the killer who claims he is a savior... (Kristeva 4)

Nagg and Nell are abject because they are poised ambiguously on the border between life and death; near corpses, falling apart, yet alive enough to push up the lids of their coffin-like dustbins to perform the daily farce of the love scene. Ghosts, of course, are similarly ambiguous. Verlaine's narrator expresses his revulsion at the spectres moving, talking, desiring bodies who look like cadavers, with their "dead eyes" and "fallen lips" (in French, note the paronomasia by which "mort" becomes "molles", creating an imperfect internal rhyme which again distils a sense of confusion throughout the line). The ghosts in Yeats are not physically repulsive (they have kept their youthful appearance), yet they too disturb the order of things and dismay the Young Man: "Who are you? What are you? You are not natural." (Yeats 2001:315) They are in fact doubly abject, as revenants and as traitors, who "sold their country into slavery" yet would be forgiven by "somebody of their race" (314), and while they claim the Young Man for their descendant, he rejects them violently by denying them forgiveness and condemning them to repeat their dance forever.

\section{By Way of Conclusion: "Against empathy" in the theatre}

What I am suggesting, then, is that these three scenes may offer an alternative ethical framework to think about theatre, one in which lack of empathy, the refusal to project oneself in the place of the Other, creates the conditions for performance, and allows for the presence of radical others on the stage. I am not, of course, advising that we, in our practice of spectatorship, should emulate the indifference or indeed hostility manifested by the three reluctant spectators in Verlaine, Yeats and Beckett; nor am I advocating the bottling of old people in dustbins. I do suggest, however, that the three scenes I have discussed invite us, paradoxically, to recognise the ethical integrity of the unempathetic spectator - one who does not presume that she can see the world from the perspective of radical Others, understand their unique circumstances, or experience their pain and vulnerability - who does not, indeed, attempt to bend the uniqueness of their experience to a grammar of the knowable and the familiar. What this might mean in practical terms remains to be thought through. What theatrical 
language can make space for Others and preserve us from the temptation of obliterating their otherness by reducing it to our own experience?

One implication, certainly, is that the sort of theatre which represents the pain of real Others in other parts of the world, courts our empathetic response and sends us home feeling good about ourselves - the sort of allegedly "political" theatre which has become so popular on Western stages - might not be the only valid paradigm for an ethically responsible theatre in the global era. It might, in fact, be less ethically pristine than is commonly assumed. I am thinking, for instance, about NT Ghent artistic director Milo Rau's 2019 show Orestes in Mosul, a multimedia theatrical metafiction where a company of Flemish actors travel to Mosul, the former capital of the Caliphate just liberated from ISIS forces and still in ruins, to stage the Oresteia with local Iraqi actors. In keeping with Rau's 2018 "Ghent Manifesto", which stipulates that at NT Ghent "at least one production per season must be rehearsed or performed in a conflict zone or war zone, without any cultural infrastructure", ${ }^{13}$ the show was devised, rehearsed and first performed in Mosul, and then played in NT Ghent and on many Western stages. The scenes involving characters played by Mosul-based actors including Iphigenia (student actor Baraa Ali), Athena (Khitam Idress), and all the chorus members - were shot in Mosul and inserted into the play in video, with occasional intermedial interaction between the European actors, playing live, and the Iraqi actors on film. The show, loosely based on Aeschylus' Oresteia, purported to explore the possibility of interrupting the chain of violence in a conflict situation, and of promoting peace and justice rather than revenge. While there is no doubt Rau and his company were well-intentioned and genuinely concerned to connect with their Iraqi counterparts in an act of artistic solidarity, the production was nonetheless ethically and politically problematic at many levels. The project was premised on the notion that the Oresteia, which dramatises the mythical origins of Western democracy, is somehow relevant to the context of the Iraqi war. It thus posited a universal framework of relevance and celebrated democracy as the solution to the devastation and multiple traumas suffered by contemporary Iraqis (the fact that the war had started with the invasion of Iraq by a coalition of Western democracies was apparently not factored into the equation). In one particularly embarrassing scene inspired by the trial of Orestes by a jury of Athenian citizens at the end of the Eumenides, the Iraqi chorus was invited to vote on the fate of ISIS killers and decide whether they should be sentenced to death or forgiven. Rau and his Belgian actors remained in Iraq altogether for two weeks, and while their project demonstrates genuine empathy, they never came close to grasping the actual, multiple, complicated wounds suffered by their Iraqi fellow-actors. As Alissa J. Rubin of the New York Times reported:

Actors like Mr. Dargham, who played a member of the chorus, saw Mr. Rau and his team arriving with preconceptions, focused on the Islamic State's invasion but seemingly oblivious to other painful episodes. Since the "Belgian group," as he called them, did not ask, he never mentioned that his father, an Iraqi army colonel, was killed by Al Qaeda when Mr. Dargham was barely 10 years old. Similarly, since Mr. Rau never inquired, he did not mention the daily difficulties that he said many of his classmates faced. "They did not ask about water, about electricity," he said. But Mr. Dargham ultimately chose to give the Europeans the benefit of the doubt. "I am sure they asked somebody else," he said. (Rubin 2019)

While the "Belgian group" knew hardly anything of the suffering of the Iraqi actors, their empathetic response to their situation prompted them to transpose it into the familiar tropes of classical Greek tragedy and represent it in terms intelligible to them 
and to their Western audiences, in an act of mistranslation in which otherness is violently cancelled out. This violence was arguably materialised in the differential performative treatment of the Iraqi group, who did not share the stage space with the Belgian group, only appearing on video. Reflecting on Levinas's ethic of responsibility - not empathy -, Kelly Oliver usefully clarifies:

We have an obligation not only to respond but also to respond in a way that opens up rather than closes off the possibility of response by others. This is what I take Levinas to mean when he says that we are responsible for the other's responsibility, that we always have one more responsibility. We are responsible for the other's ability to respond. (Oliver 18-9)

With their performance determined in advance in the paradoxical presence/absence of film, visible and audible but not, in fact, present in the same space and time as the rest of the cast and the audience, the Iraqi actors were both interpellated and divested, to use Oliver's term, of their "response-ability". Orestes in Mosul received rave reviews and played to enthusiastic audiences, and the performance I attended at the Théâtre Nanterre-Amandiers on 10 September 2019 received a standing ovation. Spectators were encouraged to empathize with the poignant fate of Mosul's population and left the theatre expressing feelings of both acute pain and a sense of moral and spiritual regeneration. Yet I would argue against this model of empathetic spectatorship which assumes that the experience of radical Others can be felt from within. To paraphrase Tammy Amiel-Houser and Adia Mendelson-Maoz in their article "Against Empathy: Levinas and Ethical Criticism in the $21^{\text {st }}$ Century": "while striving to simulate the inside experience of a [theatrical] characters, empathetic [spectatorship] becomes unethical, since it involves (even if unconsciously) an essential disregard for the inaccessible singularity of the other's experience."14 The shockingly unempathetic spectators in Verlaine, Yeats and Beckett point in a different direction, one in which spectatorship does not entail trying to know unknowable Others, but rather allowing them to appear on their own terms and to speak in their own (perhaps incomprehensible) voices, ultimately bearing witness to their appearance - as does Verlaine's ghostly narrator who, effacing himself, leaves us only with the trace of passing voices.

\section{BIBLIOGRAPHY}

Amiel-Houser, Tammy and Adia Mendelson-Maoz. "Against Empathy: Levinas and Ethical Criticism in the $21^{\text {st }}$ Century." JLT (Journal of Literary Theory) online 8:1(2014): 197-217. http:// www.jltonline.de/index.php/articles/article/view/734/1686

Aragay, Mirea. “To Begin to Speculate: Theatre Studies, Ethics and Spectatorship.” In Mirea Aragay and Enric Monteforte (eds.) Ethical Speculations in Contemporary British Theatre. Basingstoke: Palgrave Macmillan, 2014. 1-22.

Beckett, Samuel. Endgame (1958). London: Faber \& Faber, 2009.

Beckett, Samuel. The Letters of Samuel Beckett, Vol. 4: 1966-1989. George Craig, Martha Flow Fehsenfeld, Dan Gunn and Lois More Overbeck (eds.). Cambridge: Cambridge UP, 2016. 
Boyarin, Jonathan. Storm from Paradise: The Politics of Jewish Memory. Minneapolis, MN: U. of Minnesota P., 1992.

Dean, Carolyn J. The Fragility of Empathy After the Holocaust. Ithaca, NY: Cornell UP, 2004.

Dowson, Ernest. The Poems of Ernest Dowson. London: John Lane, the Bodley Head, 1905.

Grehan Helena. Performance, Ethics and Spectatorship in a Global Age. Basingstoke: Palgrave Macmillan, 2009.

Greiner, D. Rae. "Thinking of Me Thinking of You: Sympathy Versus Empathy in the Realist Novel." Victorian Studies 53:3 (2011): 417-426.

Jeffers, Alison. Refugees, Theatre and Crisis: Performing Global Identities. Basingstoke: Palgrave Macmillan, 2012.

Kristeva, Julia. Powers of Horror. An Essay on Abjection. Transl. Leon S. Roudiez. New York, NY: Columbia UP, [1980] 1982.

Lehman, Hans-Thies. Postdramatic Theatre. Trans. and intro. Karen Jürs-Munby. London: Routledge, 2006.

Longuenesse, Pierre. Yeats dramaturge. La voix et ses masques. Rennes: Presses Universitaires de Rennes, 2012.

Oliver, Kelly. Witnessing: Beyond Recognition. Minneapolis, MN: U. of Minnesota P., 2001.

Phelan, Peggy. “Marina Abramovic: Witnessing Shadows.” Theatre Journal 56 (4) 2004: 569-77.

Rau, Milo. “Ghent Manifesto.” 1 May 2018. https://www.ntgent.be/en/manifest

Read, Alan. Theatre and Everyday Life: An Ethics of Performance. London: Routledge, 2005.

Read, Alan. Theatre, Intimacy and Engagement. The Last Human Venue. Basingstoke: Palgrave Macmillan, 2009.

Ridout, Nicholas. Theatre and Ethics. Basingstoke: Palgrave Macmillan, 2009.

Rubin, Alissa J. “Can a Greek Tragedy Help Heal a Scarred City?” The New York Times, 17 April 2019. https://www.nytimes.com/2019/04/17/theater/orestes-in-mosul-milo-rau.html

Symons, Arthur. The Symbolist Movement in Literature $(1899,1919)$. Matthew Creasy (ed.). Manchester: Fyfield Books-Carcanet Press, 2014.

Verlaine, Paul. Fêtes galantes, Romances sans paroles, précédé de Poèmes saturniens. Préf. \& notes Jacques Borel. Paris: Gallimard, 2014.

Yeats, W. B. The Collected Works of W. B. Yeats, Vol. II: The Plays. David R. Clark and Rosalind E. Clark (eds.). New York, NY: Scribner, 2001.

Yeats, W. B. The Collected Works of W. B. Yeats, Vol. III: Autobiographies. William H. Donnell and Douglas N. Archibald (eds.). Basingstoke: Palgrave Macmillan, 1999.

\section{APPENDIXES}




\section{Paul Verlaine: "Colloque sentimental"}

Dans le vieux parc solitaire et glacé

Deux formes ont tout à l'heure passé.

Leurs yeux sont morts et leurs lèvres sont molles, Et l'on entend à peine leurs paroles.

Dans le vieux parc solitaire et glacé

Deux spectres ont évoqué le passé.

-Te souvient-il de notre extase ancienne?

-Pourquoi voulez-vous donc qu'il m'en souvienne?

-Ton cœur bat-il toujours à mon seul nom?

Toujours vois-tu mon âme en rêve? -Non.

Ah ! les beaux jours de bonheur indicible

Où nous joignions nos bouches ! C'est possible.

-Qu'il était bleu, le ciel, et grand, l'espoir !

-L'espoir a fui, vaincu, vers le ciel noir.

Tels ils marchaient dans les avoines folles, Et la nuit seule entendit leurs paroles.

Les Fêtes Galantes, 1869.

\section{Arthur Symons (1865-1945): “Colloque sentimental”}

In the old park, solitary and vast,

Over the frozen ground two forms once passed.

Their lips were languid and their eyes were dead, And hardly could be heard the words they said.

In the old park, solitary and vast,

Two ghosts once met to summon up the past.

-Do you remember our old ecstasy?

-Why would you bring it back again to me?

-Do you still dream as you dreamed long ago?

Does your heart beat to my heart's beating? -No.

- Ah, those old days, what joys have those days seen

When your lips met my lips! - It may have been.

-How blue the sky was, and our hope how light!

-Hope has flown helpless back into the night.

They walked through weeds withered and grasses dead, And only the night heard the words they said.

The Symbolist Movement in Literature, 1919. 


\section{Ernest Dowson (1867-1900): “After Paul Verlaine-ii - Colloque sentimental"}

Into the lonely park all frozen fast,

Awhile ago there were two forms who passed.

Lo, are their lips fallen and their eyes dead,

Hardly shall a man hear the words they said.

Into the lonely park, all frozen fast,

There came two shadows who recall the past.

"Dost thou remember our old ecstasy?"

"Wherefore should I possess that memory?"

"Doth thine heart beat at my sole name alway?

Still dost thou see my soul in visions?" "Nay!"

"They were fair days of joy unspeakable,

Whereon our lips were joined?"-“I cannot tell."

"Were not the heavens blue, was not hope high?"

"Hope has fled vanquished down the darkling sky."

So through the barren oats they wandered,

And the night only heard the words they said.

The Poems of Ernest Dowson, 1905.

\section{NOTES}

1. The phrase does not appear as such in Endgame. I use it in reference to Nagg's line, "Time for love?" which opens the sequence (Beckett 2009: 12).

2. See Aragay and Monforte (4 sq.); Jeffers (158).

3. See the Appendix for Verlaine's poem and translations by two of Verlaine and Yeats's contemporaries, Ernest Dowson (“After Paul Verlaine-ii - 'Colloque sentimental”, published 1905) and Arthur Symons ("Colloque sentimental”, published 1919).

4. At 272 rue St Jacques, the apartment of Eugénie Krantz, a prostitute known as Nini-Mouton who inspired the twenty-five poems of Chansons pour elle (1891). Yeats describes her as Verlaine's "homely middle-aged mistress" (Yeats 1999: 261).

5. For a detailed presentation of the expansion of the book between the first (1899) and second editions (1919) see the edition introduced and annotated by Matthew Creasy (Symons 2014).

6. Another point of contact between Verlaine and Yeats was Edmond Dulac, who had illustrated an edition of Verlaine's Fêtes galantes in 1910 and became Yeats's collaborator and close friend in the early 1910 s.

7. Or perhaps replace altogether, as Pierre Longuenesse suggests: "Nothing in the text tells us that the ghosts are actually dancing, or on the contrary that they are not: ultimately the decision is the director's. But to have the actors dancing on the stage may not be the best choice, since the dance is primarily happening in the words themselves." (Longuenesse 309. My translation.) While in Verlaine's poem the ghosts are materialised as voices heard by the anonymous narrator, in Yeats's symbolist version of Noh drama, they are visions who can only appear to a human character, who acts as mediator between the ghosts and the audience. They are embodied by 
actors on the stage, yet may only be figments of the Young Man's imagination. Longuenesse's suggestion that the actors need not perform the dance which the Young Man describes makes their ontological ambiguity uncomfortably palpable.

8. As Beckett made clear in a letter to Antonia Rodriguez-Gago dated 14 April 1989: "Oh les B.J. is her usual misquotation of Verlaine's Ah les B.J." (Beckett 2016: 718).

9. I am grateful to Alban Ménissier for this illuminating suggestion.

10. https://www.merriam-webster.com/dictionary/blue\%20balls

11. Aragay borrows the spelling "response-ability" from Kelly Oliver's Witnessing: Beyond Recognition (2001). In a paradigm of ethical relationships between humans inspired by Levinas, Oliver defines "response-ability", along with "address-ability", as "the roots of subjectivity", which is "the result of the process of witnessing." (7)

12. For useful recapitulations of the postmodern critique of empathy see for instance Dean (2004) and Amiel-Houser \& Mendelson-Maoz (2014).

13. https://www.ntgent.be/en/manifest.

14. "Thus, while striving to simulate the inside experience of a literary characters [sic], empathetic reading becomes unethical, since it involves (even if unconsciously) an essential disregard for the inaccessible singularity of the other's experience." (Amiel-Houser \& Mendelson-Maoz: 3)

\section{ABSTRACTS}

This paper looks at three short dramatic scenes by Paul Verlaine, W. B. Yeats and Samuel Beckett which all pick up that most conventional of theatrical themes, thwarted love, only in a disturbing way, by shifting the focus from the torments of the soul to the painful embodied experience of sexual frustration, and by having it performed not by youthful "star-crossed lovers", but by ambiguously incarnated revenants, or by decrepit, nearly dead old people. I first suggest that a certain filiation, conscious or not, runs from one of Verlaine's most famous poems, "Colloque sentimental", through the dance of the ghosts in Yeats's "play for dancers" The Dreaming of the Bones, to the "love scene" played out by Nagg and Nell out of their respective dustbins in Beckett's Endgame. More importantly, I argue that the three pieces ask uncomfortable questions about the ethics of spectatorship and invite us to think critically about the conceptualising of theatre as a "face-to-face encounter with the Other", a notion inspired by Levinas which has gained currency since the "ethical turn" hit theatre studies in the mid-2000s. This paradigm, I further suggest, is applied inaccurately to the theatrical encounter, especially in such contemporary productions as Milo Rau's 2019 show Orestes in Mosul, which rather rests on a problematic ethics of empathy, a notion foreign to Levinas. The three scenes by Verlaine, Yeats and Beckett, on the other hand, offer an alternative model of unempathetic spectatorship which, paradoxically, may go further towards allowing the presence of radical Others on the stage.

Cet article lit en parallèle trois extraits dramatiques d'œuvres de Paul Verlaine, W. B. Yeats et Samuel Beckett qui sollicitent l'éternel trope théâtral de l'amour impossible, mais de manière insolite, en insistant moins sur les tourments de l'âme que sur l'expérience douloureusement corporelle de la frustration sexuelle, et en mettant en scène non l'habituel couple de jeunes premiers, mais des spectres ambigus ou des personnages vieux, décrépits et déjà à moitié morts. Je montre d'abord qu'une filiation, consciente ou non, relie le dialogue $d u$ "Colloque 
sentimental » de Verlaine, la dance des spectres dans The Dreaming of the Bones de Yeats et la "scène d'amour" qui se joue d'une poubelle à l'autre entre Nagg et Nell dans Fin de Partie (Endgame) de Beckett. Mon hypothèse est que les trois passages, qui mettent tous en scène un spectateur involontaire, interrogent le rôle éthique du spectateur de théâtre. Depuis le "tournant éthique " des études théâtrales dans les années 2000, il est devenu courant de concevoir la représentation théâtrale comme le lieu d'une rencontre avec le Visage de l'autre, au sens où l'entend Lévinas; toutefois, cette lecture est contestable, et recouvre trop souvent la notion, étrangère à Lévinas, d'empathie. Prenant pour exemple le spectacle de Milo Rau, Orestes à Mossoul (2019), je montre en quoi un théâtre qui en appelle à l'empathie du spectateur est potentiellement problématique. Les trois scènes évoquées plus haut de Verlaine, Yeats et Beckett proposent un contre-modèle de spectateur résolument dénué d'empathie, qui permet peut-être paradoxalement de faire sur scène une place à l'Autre dans toute son irréductible étrangeté.

\section{INDEX}

Keywords: Verlaine Paul, Yeats William Butler, Beckett Samuel, Levinas Emmanuel, spectatorship, theatre, ethical criticism, empathy, Rau Milo

Mots-clés: Verlaine Paul, Yeats William Butler, Beckett Samuel, Lévinas Emmanuel, tournant éthique, théâtre, spectateur, empathie, Rau Milo

\section{AUTHOR}

\section{ALEXANDRA POULAIN}

Alexandra Poulain is Professor of postcolonial literature and theatre at Sorbonne Nouvelle University. She has published widely on modern and contemporary Irish drama and performance, with a special focus on Yeats and Beckett. Her latest book Irish Drama, Modernity and the Passion Play (Palgrave, 2016) looks at rewritings of the Passion narrative as a modality of political resistance in Irish plays from Synge to the present day. Her current research focuses on cultural and artistic representations of failure and shame in postcolonial drama, performance and the visual arts. She is currently President of the SAES and of the International Yeats Society. Contact: alexandra.poulain [at] sorbonne-nouvelle.fr 